\title{
Latent infections
}

\section{Varicella-zoster and related viruses}

\author{
K. MCCARTHY
}

From the Department of Medical Microbiology, The University of Liverpool

The phenomenal expansion in the study of latent phage infection has meant that there has been no shortage of ideas and hypotheses to explain experimental latent infections of animal cell cultures in vitro; but the greater complexity of the intact animal imposes a more complex pattern on the relationship between animal and virus so that phenomena explicable in the test tube may have scant or at best indirect relevance to the events in the intact animal. Unfortunately because of its strong cell association 'in-vitro' varicella/zoster virus is difficult to manipulate in tissue culture systems and relatively few studies in vitro have been made with it, so that when trying to piece together the mechanism of latency in man there is a dearth of laboratory data. A recent review (Taylor-Robinson and Caunt, 1972) dealing with varicells/zoster virus claims probably with justification to be comprehensive yet it contains only about 470 references, but when introducing medical students to the idea of latency the most frequently cited examples are probably herpes simplex and varicella/zoster. It is worth noting, therefore, that convincing direct laboratory evidence of varicella virus latency in man is not available and that our belief in latency following this disease is based on clinical and epidemiological evidence.

The concept of zoster as a recrudescence of an earlier varicella infection is nevertheless well founded, but for want of experimental data the picture of the mechanism of latency is patchy and incomplete.

Varicella is a disease of the highest infectivity and nearly everyone contracts it by the age of 10 years. There seems to be only one serotype and second attacks in normal individuals are extremely rare. Zoster occurs in about half of those who have had varicella and second attacks are quite common; indeed a history of zoster does not seem to alter materially the chance of a further attack in the future.
Those who suffer zoster have always, it is believed, had varicella in the past (Hope-Simpson, 1965).

That a single virus causes both conditions is no longer questioned but the communicability of the two conditions is a matter of considerable interest, particularly in respect of the kind of disease produced in the recipient. Varicella can unquestionably result from exposure to varicella or zoster cases. The question continues to be asked (Seiler, 1949; Berlin and Campbell, 1970) whether zoster can follow as the direct and immediate consequence of exposure to varicella and also whether zoster can follow consequent upon exposure to zoster. There are of course reports of such sequential events but in present circumstances the question of causality must go unanswered until more is known about the pathogenesis of both diseases. Suffice it to say that temporal association of events which are not themselves rare is bound to occur occasionally. If on occasions this association is a causal one we lack the evidence to prove it or refute it. In this connexion Thomas and Robertson (1971) have suggested a reasonable explanation of how zoster might arise from implantation of virus into the skin and cutaneous nerves of a varicella-immune subject and be channelled to the ganglion along a protected pathway. Nevertheless the three cases of zoster they describe following exposure to varicella or zoster were not closely related in time, and one of them was on treatment which might have been immunosuppressive and could have played a provocative role. This suggested explanation of causation was put to the test many years ago by Kundratitz and Lipschütz (1925) and Bruusgaard (1932). They vaccinated normal and immune subjects with varicella vesicle fluid. Varicella followed in susceptible subjects but no zoster occurred in the immune subjects. The cases of Thomas and Robertson are probably therefore examples of coincidental infection. 


\section{The Occurrence of Latency}

The facts which argue in favour of latency are that varicella is highly communicable, and has a seasonal incidence which zoster does not. Varicella follows exposure to zoster often enough for a causal relationship to be apparent, whereas the reverse association is rare enough to be accountable by chance. Strong supporting evidence that zoster represents a recrudescent infection is the fact that old people living alone who have had no recent contact with varicella in children or with zoster in adults frequently suffer from zoster attacks.

The areas most frequently affected in zoster correspond anatomically to those areas which in varicella carry the heaviest rash, for example, the face and the trunk. Hope-Simpson (1965) suggests that it is when the varicella rash is present that the virus travels up the sensory nerves from the skin to the sensory root ganglia where it remains latent.

Other findings which support the belief in latency are the common observations that lesions such as tumours or tuberculous foci or mechanical injuries in or near the spine, such as fractures, lumbar punctures, and other operations, frequently precipitate attacks of zoster in the dermatomes corresponding to the spinal level of the lesion. $X$-irradiation seems to act in a similar way (Rifkind, 1966).

The sensory ganglia are thought to be the sites of persistence of latency rather than the skin. Support for the idea of peripheral spread to the skin, and therefore for the skin not to be the site of latency, comes from the progressive spread of the rash round the dermatome and from the observation that thoracic nerve section blocks peripheral spread to the dermatome area distal to the scar. In recurrent herpes simplex the skin is probably not the site of latency since neither Rustigian, Smulow, Tye, Gibson, and Shindell (1966) nor Antonelli and Vignali (1968) could recover virus from explanted skin fragments from herpetic areas of skin cultured for many months: nor did the earlier skin graft studies of Stalder and Zurukzoglu (1936) offer any support for local persistence of herpes simplex virus in skin. Antonelli and Vignali successfully prevented $H$. simplex recurrences by surgical removal of the affected skin area but rightly did not regard this as proving the skin to be the site of persistence.

The scarcity of experimental evidence of latency in varicella arises from two causes: lack of surgical materials and a dearth of necropsy specimens. Chickenpox affects mainly children, and, being a trivial disease, there is rarely a justifiable opportunity to obtain adequate specimens for detailed consecutive study of the distribution and fate of the virus within the patient. Mortality is almost nil except in persons with an underlying defect in their defences so that necropsy material is likewise almost never available from normal cases. Helpful observations, akin to the serendipitous finding during the incubation period of measles, of giant cells in the appendix and elsewhere, have not been made. No doubt accidental surgical procedures have been undertaken in children incubating chickenpox, but the organs one might wish to sample then, or indeed later after chickenpox and before zoster, are the dorsal root and cranial nerve sensory ganglia and surgeons do not often have cause to remove these.

Meurisse (1969) attempted to isolate varicella virus after death from the fifth cranial nerve ganglion at routine necropsies not associated with recent varicella or zoster but she was not successful. Perhaps by analogy with subacute sclerosing panencephalitis it may be necessary to cultivate the human ganglion cells in organ or cell culture for many generations before latent virus, if present, becomes manifest. Meurisse adopted the more standard procedure of inoculating susceptible cell cultures with ganglion extracts, a method which, by analogy with measles and subacute sclerosing panencephalitis, might not be expected to be successful if the varicella virus is truly latent. Good organization will be called for if such a procedure is to succeed, since the viability of the ganglion cells would have to be maintained between death bed and culture tube. It seems likely but not certain that the virus is latent in the sensory neurones rather than in supporting cells since they are the cells which are seen to be intrinsically involved in zoster pathology. The prospects for successful isolation from nerve ganglia are, however, hopeful in suitable fresh necropsies since zoster ultimately occurs in about half of those who have ever had chickenpox. A recent study by Esiri and Tomlinson (1972) of postmortem material from a patient with acute zoster (who died of a myeloma), using immunofluorescent techniques and electron microscopy, has indeed shown in ganglia and Schwann cells evidence of the presence of varicella virus antigen and of virus particles.

A further handicap to the production of experimental data in vivo on the site and mechanism of latency is the difficulty in finding a suitable animal host for varicella/zoster infection. The clinical pattern in man is somewhat bizarre and probably results from an unusual and perhaps unique host-parasite interaction. Even if there were many animal hosts susceptible to the virus it is improbable that one would mimic the human disease with the production of zoster. In fact few if any animals will even support the growth of the virus, let alone show clinical signs.

Spontaneous varicella-like disease has been reported by Heuschele (1960) in three animals repre- 
senting three species of anthropoid apes-gorilla, chimpanzee, and orang utan. Clinically this appeared to be varicella. The animals had been on show and therefore in some contact with the public but no virus studies were undertaken at the time; later tests by Gold (1966) on convalescent serum from the orang utan failed to show complement-fixing antibodies so that the presumptive clinical diagnosis of varicella was probably wrong.

Klein, Milhaud, and Nicolle (1971) have reported studies on a varicella-like eruption which affected a young captive chimpanzee. Cytopathic effects were induced in tissue cultures of human amnion suggestive of a herpes group virus but the authors were unable to subculture the agent. The available histological evidence pointed to the agent being a member of the herpes group but its identity cannot be established in retrospect.

Herrmann (1969) has isolated in his laboratory a virus resembling varicella from the vesicular exanthem in a young chimpanzee at the Yerkes Primate Centre. In Herrmann's laboratory and in ours this agent has been found to resemble, but seems not to be identical with, varicella. Herrmann produced seroconversions in lower primates but not disease.

The few reported deliberate attempts to infect lower laboratory primates with varicella have probably been unsuccessful. Rivers (1926 and 1927) inoculated the testes of vervet monkeys but no evidence of clinical disease resulted. Inclusions typical of the herpes group were found in the cells of the testes while the admixture of varicella convalescent serum with the inoculum seemed to prevent this, suggesting that the cytopathology was caused by varicella virus. However, this species of monkey is now believed to be a host for several viruses of the herpes group with similar cytopathology, namely, SA6, SA8, and SA15 (Malherbe, 1963), cytomegalic virus (Black, Hartley, and Rowe, 1963), and LVV (Clarkson, Thorpe, and McCarthy 1967) so that in retrospect histological evidence on a few animals is of limited value in establishing the nature of the infection seen by Rivers.

Attempts in our laboratory (Shaw, 1968) to infect seronegative vervet monkeys (Cercopithecus aethiops), rhesus (Macaca mulatta), patas (Erythrocebus patas), and squirrel (Saimiri sciureus) were unsuccessful. No illness and no seroconversion followed. Shaw used tissue-culture propagated, cell-free virus of moderately high titre. We have not repeated the work of Rivers in which human vesicle fluid was used. However, although Shaw used cultured, and possibly attenuated, virus, the failure to show even subclinical seroconversion indicates that none of these species is likely to prove useful as an experimental animal host for varicella. Non-primates have not been found to be susceptible to varicella.

The paucity of tissue specimens for laboratory study from patients with uncomplicated varicella or frompatients recovered from the disease, and particularly from people who are about to suffer an attack of zoster, together with the lack of a suitable experimental animal host for the virus, has meant that theories about the pathogenesis of varicella zoster have had to draw on analogies with other human infections such as recurrent herpes simplex, on studies in vitro with varicella virus in tissue culture, and on animal and tissue culture studies with other related viruses.

\section{The Mechanism of Latency}

Epidemiological studies in man, while they have established the existence of virus latency following varicella as the basis, and probably the sole basis, of zoster, have contributed little or nothing to understanding the underlying mechanism of the latency and of its breakdown. Hope-Simpson (1965) suggested that declining antibody levels may be the critical factor which allows the virus existing in the ganglion cells to take on a new lease of life. The ganglion cell in the posterior root with its axon and associated sheath of Schwann cells can be regarded as a protective corridor for virus stretching from the posterior horn of the cord to the epidermis. Virus within the axon or the Schwann cells is, by analogy with herpes simplax virus, protected from antibody attack. Certainly neutralizing antibody levels in acute zoster cases are initially low, presumably having declined from a previous higher level and rise rapidly during the first few days of the eruption. Probably the scattered varicella lesions occasionally seem to accompany a zoster eruption represent virus spilled from infected ganglion cells or from supporting cells and spread by blood to the skin and not neutralized because antibody rise in a particular case is delayed slightly or is deficient. But virus remaining within the corridor of the neuronal cell or its associated Schwann cells must surely be safe from antibody so that antibody is unlikely to be the restraining influence preventing early zoster. Hope-Simpson's (1965) suggestion concerning the role of antibody does not therefore seem acceptable.

The mechanisms which establish, maintain, and temporarily expose the state of latency in varicella/ zoster must be sought within the carrier cell or between it and associated cells. There is histological evidence of virus infection of the cell body of the neuron in posterior root ganglia in active zoster just as there is in experimental herpes simplex infections in animals (Fenner, 1968). There is also evidence that in experimental herpes infections in animals, 
with several different model systems, spread to and from the ganglion is by means of the perineural cells rather than by axonal transmission, and there is now evidence to indicate the repository site during latency. Stevens, Nesburn, and Cook (1972) report the isolation of virus from the trigeminal ganglion in rabbits with recurrent $H$. simplex eye infections. They were successful only when the ganglion cells were grown out in organ culture. An apparently new, non-cellassociated simian herpes virus which we have recently isolated from owl monkeys (Aotus trivirgatus) and which is immunologically related to $\boldsymbol{H}$. tamarinus, seems also to hold our promise as a model system, since cutaneous infection seems to spread centrally only as far as the sensory ganglia with radicular sensory loss. Unlike the Herpes simplex eye infection studied by Stevens, Nesburn, and Cook (1972), however, spontaneous recurrence has not yet been seen.

Since in zoster a fairly extensive search has failed to reveal live vegetative virus in trigeminal ganglia (Meurisse, 1969) at routine necropsies, and since before zoster occurs no re-stimulation of antibody seems to be taking place (Caunt and Shaw, 1969) it seems likely that production of vegetative antigenic virions, whether in neurone or Schwann cell, is either proceeding very slowly or is shut off. Persistent productive virus infection of tissue culture cells can be established, and interferon or some similar effect seems to play a causal role: antibody is not necessary for this chronicity in vitro (Géder, Váczi, and Koller, 1965). It is possible that virus could persist in ganglia in this fashion where cell death and replacement might balance virus growth, but vegetative growth of varicella virus seems, at least in vitro, to involve cell death, so that a chronic persistent infection of this kind could hardly be maintained in neurones which intrinsically cannot replace themselves. Persistent productive growth in Schwann cells is a possibility, but the persistent growth of vegetative virus in an immunologically competent host would be expected to maintain high antibody levels and these are not found.

It seems more likely, therefore, that in man virus persists more or less integrated into the DNA of the host cell genome. Neurones having a low turnover of host DNA would be expected to offer fewer opportunities for the incorporated viral genome to segregate from host DNA and re-establish productive infection. This would favour long-term inapparent persistence in a latent and non-antigenic form which would better fit the observed facts. It would, however, imply a departure from the usual consequence of DNA virus infection of cells. In most instances infection is either productive and lethal or unproductive but associated with transformation. Perhaps the non-replicating nature of neurones prevents transformation or at least prevents the consequences of transformation. A search for varicella-specific $T$ antigens in apparently healthy ganglion cells might throw light on these possibilities.

Persistence in Schwann cells in latent form seems less likely, because these cells very readily multiply in the host, eg, during repair to injured nerves, so that they would appear less suitable cells for longterm latency without transformation.

There is, however, another characteristic of varicella/zoster virus which may in part be responsible for persistent non-infective carriage, namely, the high degree of cell association seen in tissue cultured virus.

The infective/total particle ratio of virus propagated in cell monolayers derived from human skin is less than 1 in $10^{9}$ yet virus propagated in the same tissue in the skin of a human being, or in skin maintained as organized cultures of fragments of whole skin with a similar total count, may have a free virus infective titre as high as $10^{5}$ infective particles per $\mathrm{ml}$, corresponding to an infective/total ratio of about 1 in $10^{4}$. Thus varicella seems to be a virus sometimes strongly cell-associated and sometimes productive of considerable amounts of free infective virus, depending perhaps on the organization of the cells in which it is grown (Caunt, 1963; Caunt and Taylor-Robinson, 1964; Caunt, 1969). Whether non-infective virions are present during the period of latency in the cells of human sensory ganglia is not known, since no report of any electron microscopical study of such ganglia has appeared. However, the finding by Esiri and Tomlinson (1972) of specific fluorescence and virus particles in acute zoster suggests that such a study might prove worthwhile. Nevertheless persistence of infection with the production of non-infective virions in vivo seems unlikely in view of the lack of antigenicity of the latent state.

The possibility that varicella latency was in some way tied up with the strong cell-associated nature of the cultured virus had been a subject for speculation without experiment for some time. Varicella was until recently thought to have no close analogues in the animal world for experimental study. Therefore the isolation of a similar strongly cell-associated herpes virus from a varicella-like disease in vervet monkeys (Clarkson, Thorpe, and McCarthy, 1967) seemed to offer hope of a model system for experimental study. Since that time four other cell-associated simian herpes viruses have been isolated, which were all found initially as causes of generalized exanthematous diseases in laboratory primates (McCarthy, Thorpe, Laursen, Heymann, and Beale, 1968; Ayres, 1969; Tauraso, 1970; Herrmann, 1969). 
Immunological relationships with varicella have been demonstrated in three of these so far, and with the two agents isolated in our laboratory tissue culture passage has brought about sufficient attenuation to allow survival of inoculated animals. This group of agents, though difficult to handle experimentally because of their infectivity being strongly cell-associated, nevertheless seem to be promising agents for future studies of latency. But so far, in animals surviving infection over several years no clinical evidence of recurrent infection has been noticed, and wo have not yet sought for latent virus in necropsy specimens.

\section{Conclusion}

Varicella and zoster are manifestations of the same virus infection. Virus persists following varicella in a form which preserves the genome of the virus unaltered, but the mode of persistence is not known. Zoster arises when the restriction on virus replication is removed but again the mechanism for de-repression is not known.

It seems probable that virions, whether infective or incomplete, are not present during latency, or are present in only small numbers, since antibody is not maintained and an absence of antigenic stimulus can be presumed.

The path to and from the sensory ganglia is probably the continuum of Schwann cells surrounding sensory nerves but the neurone cell body seems more likely as the site of long-term persistence.

So far no entirely suitable animal model systems have been developed for work with this virus, and the development of new ideas is handicapped by this and by a dearth of suitable biopsy and necropsy tissues for investigation by available techniques.

\section{References}

Antonelli, A., and Vignali, C. (1968). Ricerche sulla localizzazione del virus dell' herpes simplex dopo guarigione delle recidive cutanee: coltivazione di cellale della zona colpita da eruzione recidivante. Riv. Ist. sieroter. ital., 43, 43-51.

Ayres, J. P. (1969). Personal communication.

Berlin, B. S., and Campbell, T. (1970). Hospital-acquired herpes zoster following exposure to chickenpox. J. Amer. med. Ass., 211, 1831-1833.

Black, P. H., Hartley, J. W., and Rowe, W. P. (1963). Isolation of a eytomegalovirus from African green monkey. Proc. Soc. exp. Biol. (N.Y.), 112, 601-605.

Bruusgaard, E. (1932). The mutual relation between zoster and varicella. Brit. J. Derm. Syph., 44, 1-24.
Caunt, A. E. (1963). Growth of varicella-zoster virus in human thyroid tissue cultures. Lancet, 2, 982-983.

Caunt, A. E. (1969). The growth of varicella-zoster virus in tissue fragments. Brit. J. exp. Path., 50, 26-31.

Caunt, A. E., and Shaw, D. G. (1969). Neutralization tests with varicella-zoster virus. J. Hyg. (Lond.), 67, 343-352.

Caunt, A. E., and Taylor-Robinson, D. (1964). Cell-free varicellazoster virus in tissue culture. J. Hyg. (Lond.), 62, 413-424.

Clarkson, M. J., Thorpe, E., and McCarthy, K. (1967). A virus disease of captive vervet monkeys (Cercopithecus aethiops) caused by a new herpesvirus. Arch. ges. Virusforsch., 22, 219-234.

Esiri, M. M., and Tomlinson, A. H. (1972). Herpes zoster. Demonstration of virus in trigeminal nerve and ganglion by immunofluorescence and electron microscopy. J. neurol. Sci., 15, 35-48.

Fenner, F. J. (1968). The Biology of Animal Viruses. Academic Press, New York and London.

Géder, L., Váczi, L., and Koller, M. (1965). Persistent varicella and herpes simplex virus infection of a continuous monkey kidney cell culture. Acta. virol., 9, 431-436.

Gold, E. (1966). Serologic and virus-isolation studies of patients with varicella or herpes-zoster infection. New Engl. J. Med., 274, 181-185.

Herrmann, K. L. (1969). Personal communication.

Heuschele, W. P. (1960). Varicella (chicken pox) in three young anthropoid apes. J. Amer. vet. med. Ass., 136, 256-257.

Hope-Simpson, R. E. (1965). The nature of herpes zoster: a long term study and a new hypothesis. Proc. roy. Soc. Med., 58, 9-20.

Klein, M., Milhaud, C., and Nicolle, R. (1971). Notes on an isolated case of viral eruption observed in a colony of chimpanzees. Lab. Primate Newsletter, 10, No. 2, 20-23.

Kundratitz, K., and Lipschütz, B. (1925). Ueber die Aetiologie des Zoster und ueber seine Beziehungen zu Varizellen. Wien. klin. Wschr., 38, 499-503.

Malherbe, H., and Harwin, R. (1963). The cytopathic effects of vervet monkey viruses. $S$. Afr. med. J., 37, 407-411.

McCarthy, K., Thorpe, E., Laursen, A. C., Heymann, C. S., and Beale, A. J. (1968). Exanthematous disease in patas monkeys caused by a herpes virus. Lancet, 2, 856-857.

Meurisse, E. V. (1969). Laboratory studies on the varicella-zoster virus. J. med. Microbiol., 2, 317-325.

Rifkind, D. (1966). The activation of varicella-zoster virus infections by immunosuppressive therapy. J. Lab. clin. Med., 68, 463-474.

Rivers, T. M. (1926). Nuclear inclusions in the testicles of monkeys injected with the tissue of human varicella lesions. J. exp. Med., 43, 275-287.

Rivers, T. M. (1927). Varicella in monkeys. Nuclear inclusions produced by varicella virus in the testicles of monkeys. J. exp. Med. 45, 961-968.

Rustigian, R., Smulow, J. B., Tye, M., Gibson, W. A., and Shindell, E. (1966). Studies on latent infection of skin and oral mucosa in individuals with recurrent herpes simplex. J. invest. Derm., 47, 218-221.

Seiler, H. E. (1949). A study of herpes zoster particularly in its relationship to chickenpox. J. Hyg. (Lond.), 47, 253-262.

Shaw, D. G. (1968). Laboratory studies in varicella-zoster virus. PhD Thesis, Liverpool University.

Stalder, W., and Zurukzoglu, S. (1936). Experimentelle Untersuchungen uber Herpes. Transplantation herpesinfizierter Hautstellen, Reaktivierung von abgeheilten, künstlich infizierten Hautstellen, Herpesbehandlung. VI. Mitteilung. Zbl. Bakt. I. Abt. Orig., 136, 94-97.

Stevens, J. G., Nesburn, A. B., and Cook, M. L. (1972). Latent herpes simplex virus from trigeminal ganglia of rabbits with recurrent eye infection. Nature new Biol., 235, 216-217.

Tauraso, N. (1970). Personal communication.

Taylor-Robinson, D., and Caunt, A.E.(1972). Varicella Virus. Virology Monograph, in press. Springer, Berlin and New York.

Thomas, M., and Robertson, W. J. (1971). Dermal transmission of virus as a cause of shingles. Lancet, 2, 1349-1350. 